\title{
The Neanderthal mandible BD 1 from La Chaise-de- Vouthon Abri Bourgeois-Delaunay (Charente, Southwestern France, OIS 5e). Dental tissue proportions, cortical bone distribution and endostructural asymmetry
}

La mandibule néandertalienne BD 1 de la Chaise-de-Vouthon Abri BourgeoisDelaunay (Charente, Sud-Ouest de la France, OIS 5e). Proportions des tissus dentaires, distribution de l'os cortical et asymétrie endostructurale

Clément Zanolli, Lisa Genochio, Jean-François Tournepiche, Arnaud Mazurier and Roberto Macchiarelli

\section{(2) OpenEdition}

\section{Journals}

Electronic version

URL: http://journals.openedition.org/paleo/5847

DOI: $10.4000 /$ paleo.5847

ISSN: 2101-0420

\section{Publisher}

SAMRA

Printed version

Date of publication: 1 September 2020

Number of pages: 346-359

ISSN: 1145-3370

\section{Electronic reference}

Clément Zanolli, Lisa Genochio, Jean-François Tournepiche, Arnaud Mazurier and Roberto Macchiarelli, «The Neanderthal mandible BD 1 from La Chaise-de-Vouthon Abri Bourgeois-Delaunay (Charente, Southwestern France, OIS 5e). Dental tissue proportions, cortical bone distribution and endostructural asymmetry », PALEO [Online], 30-2 | 2020, Online since 30 September 2020, connection on 26 November 2020. URL : http://journals.openedition.org/paleo/5847 ; DOI : https://doi.org/ $10.4000 /$ paleo.5847

\section{(c) (†) $\ominus$}

PALEO est mis à disposition selon les termes de la licence Creative Commons Attribution - Pas d'Utilisation Commerciale - Pas de Modification 4.0 International. 
THE NEANDERTHAL

MANDIBLE BD 1 FROM

LA CHAISE-DE-VOUTHON

ABRI BOURGEOIS-

DELAUNAY (CHARENTE,

SOUTHWESTERN FRANCE,

OIS 5E).

DENTAL TISSUE

PROPORTIONS,

CORTICAL BONE

DISTRIBUTION

AND ENDOSTRUCTURAL

ASYMMETRY

Clément Zanollia, Lisa Genochiob, Jean-François Tournepichec, Arnaud Mazurier ${ }^{\text {, }}$ Roberto Macchiarellie

a. UMR 5199 CNRS, Université de Bordeaux FR - 33615 Pessac cedex -

clement.zanolli@gmail.com

b. Department of Archaeology and Hull York Medical School, University of

York, York, UK - lisa.gh@free.fr

c. Musée d'Angoulême FR - 16000 Angoulême - Jftbill@aol.com

d. UMR 7285 CNRS, Institut de Chimie des Milieux et Matériaux, Université de Poitiers FR - 86073 Poitiers - arnaud.mazurier@univ-poitiers.fr

e. Département Homme et Environnement, UMR 7194 CNRS, Muséum national d'histoire naturelle, Musée de l'Homme FR - 75013 Paris. Unité de Formation Géosciences, Université de Poitiers FR - 86073 Poitiers -

roberto.macchiarelli@univ-poitiers.fr

PALEO 30 | t. 2

JUILLET 2020

PAGES 346 À 359

KEY-WORDS La Chaise-de-Vouthon, Eemian, Neanderthal mandible, tooth endostructure, cortical bone thickness, asymmetry.
The 23 fossil human remains found at La Chaise-deVouthon Abri Bourgeois-Delaunay (Charente, Southwestern France) are all attributed to Neanderthals. The BD 1 mandible represents one of the best preserved specimens recovered in this assemblage, still bearing the entire set of 16 teeth, and attributed to an adult - likely 20-35 years old individual. The geochronological and paleontological data indicate that the Neanderthals from Abri Bourgeois-Delaunay lived in a temperate environment between 127 and $116 \mathrm{ka}$ (i.e., during the OIS 5e). In this study, we integrate and expand the morphometric record of $B D 1$ by quantifying the tissue proportions of its entire permanent dentition, including radicular thickness repartition of four front teeth, and comparing its degree of endostructural asymmetry in tooth tissue organization and postcanine cortical bone topography with the patterns shown by Regourdou 1. Our results show that crown and radicular dental internal signature is typically Neanderthal, comparable with the available data for Regourdou 1, and is unambiguously distinct from the fossil and extant modern human patterns. Asymmetry in tooth tissue proportions in BD 1 and Regourdou 1 is clearly non-directional, as side dominance is nearly equally distributed between the left and the right antimeres. Similarly, both Neanderthal mandibles show no marked cortical bone asymmetry at the molar level, even if a slight right dominance is found in BD 1. Even if these results are globally consistent for the two Neanderthal mandible, extensive methodological research on the patterns of age- and sex-related endostructural variation displayed by human population samples from diverse chrono-geographic, socio-economic and biocultural contexts is still needed to more confidently evaluate the evolutionary and adaptive significance of the signals from the fossil record. 
de-Vouthon Abri Bourgeois-Delaunay (Charente, Sud-Ouest de la France, OIS 5e). Proportions des tissus dentaires, distribution de l'os cortical et asymétrie endostructurale.

Les 23 restes humains fossiles découverts à La Chaise-de-Vouthon Abri Bourgeois-Delaunay (Charente, Sud-Ouest de la France) sont tous attribués à des Néandertaliens. La mandibule BD 1 représente un des spécimens les mieux préservés de l'assemblage, conservant encore ses 16 dents, et a été attribuée à un individu adulte vraisemblablement âgé d'environ 20-35 ans. Les données géochronologiques et paléontologiques indiquent que les Néandertaliens de l'Abri Bourgeois-Delaunay vivaient dans un environnement tempéré il y a environ 127 à 116 ka (i.e., pendant l'OIS 5e). Dans cette étude, nous apportons des informations morphométriques complémentaires sur la structure de BD 1 en quantifiant les proportions des tissus de l'ensemble de ses dents permanentes, incluant la distribution d'épaisseur de dentine radiculaire de quatre dents antérieures, et en comparant le degré d'asymétrie endostructurale de l'organisation des tissus dentaires et de la topographie de l'os cortical au niveau des dents post-canines avec les patrons structuraux de Regourdou 1. Nos résultats montrent que la signature interne de la couronne et de la racine des dents est typiquement néandertalienne, comparable à celle de Regourdou 1, et clairement distincte des patrons humains modernes fossile et actuel. L'asymétrie des proportions des tissus dentaires de BD 1 et Regourdou 1 est non-directionnelle, sans dominance marquée entre les antimères gauches et droits. De la même manière, les deux mandibules néandertaliennes ne montrent pas de d'asymétrie marquée d'épaisseur de l'os cortical au niveau des molaires, même si une faible dominance droite est observée chez BD 1. Même si ces résultats sont globalement concordants pour les deux mandibules néandertaliennes, l'étude méthodologique étendue des patrons de variation de l'endostructure liés à l'âge et au sexe montrée par des populations humaines issues de divers contextes chrono-géographiques, socio-économiques et bioculturels reste nécessaire afin de mieux évaluer la valeur évolutive et adaptative des signaux observés dans le registre fossile.

MOTS-CLÉS La Chaise-de-Vouthon, Eémien, mandibule néandertalienne, endostructure dentaire, épaisseur corticale, asymétrie.

\section{INTRODUCTION}

The Middle to Late Pleistocene site complex of La Chaisede-Vouthon, in the department of Charente, western France, is located on the left bank of an affluent of the Charente River, the Tardoire. It is located within a Middle Jurassic (Bajocian/Bathonian) limestone platform which underwent intense erosion across the Cenozoic (Tournepiche 1998) resulting in the formation of a network of mainly NW-oriented rock shelters and karstic cavities. The galleries extend over several tens of meters and open out c. $10 \mathrm{~m}$ above the Tardoire River through three main cave shelters («porches»): Duport, Bourgeois-Delaunay and Suard (Debénath 1974a, 1977, 2006). This prehistoric locality was discovered in 1850 by J. Fermond and, following some preliminary field work conducted since 1865 by the abbots Bourgeois and Delaunay, it was excavated starting in the " 30 s by P. David, especially between 1945 and 1963, and then by A. Debénath, between 1967 and 1983 (Debénath 1974a, 1992, 2006; Debénath and Tournepiche 1996).

Human fossil remains at La Chaise-de-Vouthon, all attributed to Neanderthals, have been so far discovered at the Abri Suard, the Abri Bourgeois-Delaunay and, more recently, at the Tour of La Chaise cave («grotte de la Tour»). The deposits of the Abri Suard and Abri BourgeoisDelaunay, mostly of lacustrine origin and covered by a colluvial sequence intercalated with slump deposits and speleothems (Bertran 1999), were originally referred to a period ranging from Riss II to Riss-Würm, and from Riss III to Würm III, respectively (Debénath 1974a, 1977, 2006; Schvoerer et al. 1977; Schwarcz and Debénath 1979; Blackwell et al. 1983, 1990, 1992). According to a set of ${ }^{230} \mathrm{Th} /{ }^{234} \mathrm{U}$ speleothem dates (Couchoud 2006; Vieillevigne et al. 2008), the human remains from the Abri Suard, associated to a typically cold mammal fauna (Griggo 1996; see also Bouchud and Bouchud 1953; David and Prat 1965), belong to the Oxygen Isotope Stage (OIS) 6 and are likely younger than 163 thousand years (ka), while the age of the human fossil assemblage from Bourgeois-Delaunay, associated to a temperate fauna (Armand 1998; see also David and Prat 1965), is estimated between 127 and $116 \mathrm{ka}$, i.e., to the OIS 5e (Debénath 2006). The Tour of La Chaise cave, located about $130 \mathrm{~m}$ W of the Suard rock shelter, was discovered in 2006 during speleological exploration. So far, it has provided a fossil human femoral shaft from a typically hyena den context whose mammal assemblage suggests a chronological attribution to the OIS 3 (Puymerail et al. 2012; cf. Tournepiche 1996, 2010).

The human fossil record from La Chaise-de-Vouthon consists of a whole of at least 76 dental (including isolated teeth), cranial and postcranial remains representing subadult and adult individuals. Specifically, 52 specimens come from Suard, 23 from Bourgeois-Delaunay and one from the Tour of La Chaise (David and Bordes 1950; David and Piveteau 1953a, b; Piveteau 1955, 1970; Debénath 1967, 1974b, 1977; Debénath and Piveteau 1969; Genet-Varcin 1974, 1975a, b, 1976; Thoma 1975; Legoux 1976; Lacombe 1977 . Saban 1978; Krukoff 1979; Hublin 1980; Tillier and GenetVarcin 1980; Piveteau and Condemi 1988; Coqueugniot et al. 1996; Condemi 2001; Teilhol 2001, 2003; Macchiarelli et al. 2006, 2007; Puymerail et al. 2012, 2013; an exhaustive list of the anthropological studies before the " 90 s can be found in Debénath 1992). 
One remarkable specimen among those forming the Abri Bourgeois-Delaunay's human fossil assemblage is represented by the adult mandible $\mathrm{BD} 1$, bearing the entire set of 16 teeth. Recovered on September $12^{\text {th }} 1967$ (Debénath 1967, 1974b), the specimen was described in detail by Condemi (2001). In agreement with the associated geochronological and technocultural context, the morphological and dimensional affinities (Condemi 2001: tables VII-1 and VII-2) of BD 1 indicate that it belongs to a Neanderthal individual likely 20-35 years old (Condemi 2001).

\section{Research goals}

Intra-individual antimeric variation in tooth size is considered a measure of developmental instability, and fluctuating vs. directional odontometric asymmetry is used to assess the amount of relative stress a population experienced (e.g., Corruccini et al. 2005; Hoover et al. 2005; Guatelli-Steinberg et al. 2006; Rizk et al. 2013; Scott et al. 2018). However, because of the usually advanced degree of occlusal crown wear, such external measures are barely useful in the study of fossil specimens, where an alternative approach consists in assessing antimeric variation in tooth tissue proportions and root size (e.g., Braga et al. 2010; Kupczik and Hublin 2010; Prado-Simón et al. 2012; Macchiarelli et al. 2013). With this respect, a previous study on three-dimensional (3D) endostructural asymmetry assessed on the complete dentition of the adult Neanderthal mandible Regourdou 1 (Maureille et al. 2001), likely of comparable age at death of BD 1 (Volpato et al. 2012), has revealed some discrepancies in antimeric variation between the signals provided by the outer tooth crowns and the proportions displayed by their inner tissue components (Macchiarelli et al. 2013). Specifically, mostly based on a quantitative parameter often used to characterize endostructural tooth organization, i.e., the percent of crown volume that is dentine and pulp, the study has shown that antimeric variation in Regourdou 1 is fluctuating (i.e., non-directional) and globally modest (Macchiarelli et al. 2013). Additionally, a recent structural analysis of the same specimen has revealed a likely functional link among degree of occlusal wear, root dentine thickness variation and site-specific variation in cortical bone distribution (Fiorenza et al. 2019). However, no comparative endostructural evidence from the complete permanent dentition of other Neanderthals is currently available.

In the present study, we integrate and expand the morphometric record of BD 1 (Condemi 2001) by quantifying the tissue proportions of its entire permanent dentition, including radicular thickness repartition of four front teeth, and comparing its degree of endostructural asymmetry in tooth tissue organization and postcanine cortical bone topography with the patterns shown by Regourdou 1 (Macchiarelli et al. 2008, 2013; Fiorenza et al. 2019).

\section{MATERIALS}

BD 1 - Because of its in situ anatomical orientation, the slightly obliquely oriented dental arcade facing downwards, BD 1 suffered some breakage and bone loss, notably at the level of the nearly completely missing left ramus and of large portions of the body and of the perialveolar bone anterior to both first molars. Parts of the missing symphyseal region and the lower margin of the mental protuberance have been reconstructed by plaster to provide support to the incisor, canine and premolar teeth of both sides, whose roots are completely exposed (Condemi 2001: photos VII-1 to VII-8 and photo VIII-6; figs VII-1 to VII-5 and fig. VIII-9). As seen in anterior and posterior views, relatively large bony flakes are also missing at different points of the body, especially on the posterior aspect of the specimen. Nonetheless, following careful consolidation and restoration, BD 1 preserves a large portion of the right ramus, including most of the coronoid process, the mandibular notch and the condyle, as well as the postcanine body portion of both sides. The dentition, including the third molars, is complete and all crowns are rather well preserved with modest postdepositional damages. However, on the right side, the lower half of the root of the central incisor and the entire root of the canine are missing. Despite some locally exposed dentine patches, especially on the first molars, postcanine occlusal wear in this individual is moderate and relatively homogeneously spread between the antimeres, while occlusal enamel has been almost entirely removed on the incisors and, to a lesser extent, on the canines.

Regourdou 1 (R1) - For the purposes of the present study, we compared the BD 1's dental and bony endostructural features to those virtually extracted from the OIS 4 (71$57 \mathrm{ka}$ ) mandible Regourdou 1, from the eponym site at Montignac-sur-Vézére, in Dordogne (France) (Piveteau, 1959; for details and an historical review, see Maureille et al. 2015a, b). The R1 nearly intact mandible, just slightly more robust compared to BD 1 (Condemi 2001: tables VII1 and $\mathrm{VII}-2$ ), presents a complete set of teeth showing a degree of occlusal wear macroscopically comparable to that of the specimen from the abri Bourgeois-Delaunay (Maureille et al. 2001; Macchiarelli et al. 2008, 2013; Volpato et al. 2012; Fiorenza et al. 2019;). However, Maureille et al. (2001) observed that in R1 the teeth of the right arcade were slightly more worn than their antimeres, a characteristic recently supported for the posterior dentition by the quantitative analysis performed by Fiorenza et al. (2019). This asymmetric pattern was also investigated by Volpato et al. (2012). By assessing the orientation of the microwear striations over the labial surfaces of incisors and canines, they concluded that the predominance in $\mathrm{R} 1$ of right oblique scratches, typical of right-handed manipulations, was probably caused by the use of the anterior teeth as a vice or a third hand. In this specimen, enamel thickness asymmetry was also found on the postcanine teeth, especially between the third premolars (Macchiarelli et al. 2013; Fiorenza et al. 2019).

\section{METHODS OF ANALYSIS}

Both mandibles BD 1 and Regourdou 1 were scanned in 2005 at the beamline ID 17 of the European Synchrotron Radiation Facility, Grenoble, France (experiment SC1587c), according to the following parameters: energy, $70 \mathrm{keV}$; projections, 1500 in half acquisition mode; integration time, $22.9 \mathrm{~ms}$. The final sections were reconstructed from sinograms and saved in a 32-bit floating-point raw format 
at a voxel size of $45.5^{\star} 45.5^{\star} 45.7 \mu \mathrm{m}$ for the scans of the teeth and with an isotropic voxel size of $350 \mu \mathrm{m}$ for the whole mandible.

We used routinely applied standard procedures of semiautomatic threshold-based segmentation to virtually reconstruct tooth volume (for technical details, see Kono 2004; Macchiarelli et al. 2006; Olejniczak et al. 2008; Zanolli et al. 2014, 2018).

A $3 D$ virtual rendering of $B D 1$ in various perspectives is provided in figure 1.

\section{Enamel thickness distribution maps}

For all teeth of both arcades, enamel occlusal distribution and thickness variation (occlusal-labial for the front teeth) were comparatively rendered in BD 1 and Regourdou 1 through 3D topographic mapping (cartographies) generated using a tooth-specific chromatic scale, where thickness increases from dark blue (thinner enamel) to red (thicker enamel) and white indicates emerging underlying dentine patches (cf. Macchiarelli et al. 2008, 2013; Bayle et al. 2011; Zanolli 2015).

\section{Dental tissue proportions}

Twelve linear, surface, and volumetric variables describing tooth structural organization and proportions were measured or calculated for each virtually extracted tooth: volume of enamel cap $\left(\mathrm{Ve}, \mathrm{mm}^{3}\right)$; total volume of dentine $\left(\mathrm{Vd}, \mathrm{mm}^{3}\right)$; total volume of pulp $\left(\mathrm{Vp}, \mathrm{mm}^{3}\right)$; total volume of cementum (Vcem, $\mathrm{mm}^{3}$; not available for Regourdou 1); total tooth volume $\left(\mathrm{Vt}, \mathrm{mm}^{3}\right)$; volume of crown dentine + pulp (Vcdp, $\left.\mathrm{mm}^{3}\right)$; volume of the root dentine + pulp (Vrdp, $\mathrm{mm}^{3}$; not available for Regourdou 1); surface area of enamel-dentine junction (SEDJ, $\mathrm{mm}^{2}$ ); percent of crown volume that is dentine and pulp (Vcdp/Vc, \%); percent of the root volume that is cementum (Vcem/Vrdp, \%; not available for Regourdou 1); 3D average enamel thickness (3D AET, $\mathrm{mm}$ ); the scale-free 3D relative enamel thickness (3D RET).

\section{Radicular dentine thickness distribution}

To assess root dentine thickness repartition in the BD 1's front teeth (except for the roots of the right central incisor and canine, respectively incomplete and absent) and to compare this topographic pattern with that displayed by Regourdou 1, in each available specimen we virtually unzipped the $15-85 \%$ portion (15\% being closer to the dental cervix) of the total root length along a predefined vertical line established at the middle of the labial aspect. By using a custom routine developed in R v.3.6 ( $R$ Development Core Team 2019) with the packages Momocs (Bonhomme et al. 2014), spatstat (Baddeley et al. 2015) and gstat (Pebesma 2004), we then virtually unrolled it and projected its local properties into a morphometric map (Bondioli et al. 2010; Bayle et al. 2011; Macchiarelli et al. 2013; Zanolli et al. 2014, 2018). In the analysis, dentine thickness values have been standardized between 0 and 1 and each morphometric map has been set within a grid of 90 rows and 100 columns.

\section{Cortical bone distribution}

As previously noted, the BD 1's corpus presents on both sides some taphonomic breaks and local bone loss that complicate the task of reliably assessing structural variation of the cortical shell at volumetric scale. However, following the segmentation procedure recently applied to the Regourdou 1 mandible (for technical details, see Fiorenza et al. 2019), it was possible to confidently separate its endosteal surface from the immediately underlying
A

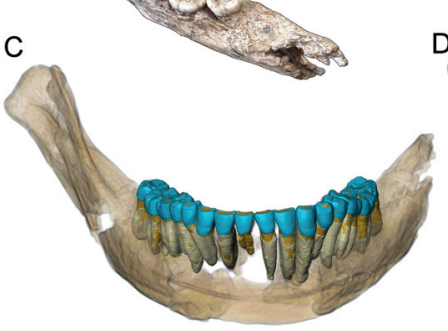

E

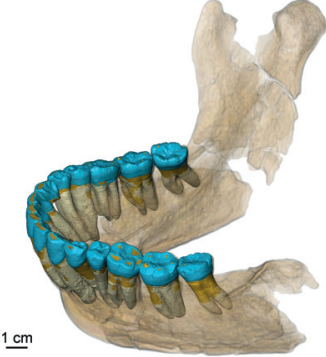

B

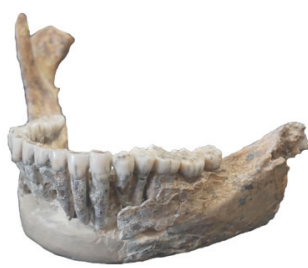

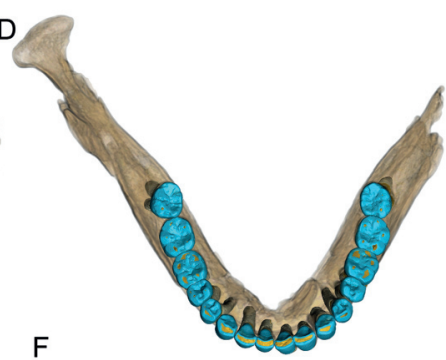

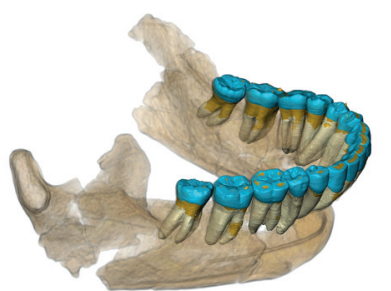

\section{FIGURE 1}

Photographs in superior view from the left side (A) and in lateral view showing the reconstructed portion of the inferoanterior aspect of the Neanderthal mandible BD 1 (B), and microtomographic-based 3D rendering in semi-transparency of the specimen in anterior (C), superior (D), slightly obliquely-oriented lateral left (E), and slightly obliquely-oriented lateral right (F) views. Note that the reconstructed part of the symphyses made with plaster (A) was reinforced using a bended transverse metallic bar visible on the virtual renderings (C-F). Scale bar: $1 \mathrm{~cm}$.

Photographies en vue supérieure depuis le côté gauche (A) et en vue latérale montrant la portion reconstruite de l'aspect inféro-antérieur de la mandibule néandertalienne BD 1 (B), et rendus 3D en semi-transparence basés sur le registre microtomographique du spécimen en vues antérieure (A), supérieure (B), latérales gauche (C) et droite (D) légèrement obliques. Echelle: $1 \mathrm{~cm}$. 
cancellous bone. We then measured left vs. right cortical bone topographic thickness distribution on two buccolingual slices taken perpendicular to the occlusal plane and virtually extracted between the first and second molars (M1/M2) and between the second and third molars (M2/M3), respectively. The upper limit of each section was arbitrarily established immediately below the perialveolar area, where cortical bone wears thin (Zanolli et al. 2017). For comparison, the homologous slices were extracted on Regourdou 1. In processing the record of the two fossil specimens, minor local discontinuities along the periosteal and endosteal contours were virtually integrated by manual corrections. In the four extracted individual slices (two for each side on each mandible), cortical bone thickness topographic variation was measured by computing the distance between the periosteal and endosteal surfaces of the cortical shell where, for each point of one surface, the closest point on the other surface was computed (Fiorenza et al. 2019). Visualization of bone thickness variation has been rendered using the R v.3.6 package ggplot2 3.2 (Wickman 2016). To allow direct comparisons between BD 1, proportionally smaller, and Regourdou 1, proportionally larger, we calculated the scale-free bi-dimensional (2D) Relative Cortical Thickness (2D RCT) index (see Cazenave et al. 2017). It is given as the average cortical thickness (2D ACT) multiplied by 100 and divided by the square root of the trabecular area (TBA, in $\left.\mathrm{mm}^{2}\right)(2 \mathrm{D} R C T=2 \mathrm{DACT} x$ $100 /$ TBA $^{1 / 2}$ ), where $2 \mathrm{D} A C T$ is the ratio between cortical area $\left(\mathrm{CA}\right.$, in $\mathrm{mm}^{2}$ ) and the endosteal contour length (in $\mathrm{mm}$ ).

\section{Asymmetry}

For each variable measurable on both dental antimeres (84/96 of cases) and on two cortical bone virtual sections (2D RCT), percent asymmetry was calculated as: $(L-R) /\left([L+R]^{*} 0.5\right)$, where $L$ and $R$ correspond to the left and right side, respectively (Corruccini et al. 2005).

\section{RESULTS}

\section{Enamel thickness distribution maps}

In terms of amount and patterns of macroscopic occlusal crown wear (cf. Smith 1984) and of left vs. right side distribution, BD 1 and Regourdou 1 are globally comparable (fig. 2), the only exception being represented by the peculiar wear pattern displayed by the left P3 in Regourdou 1 (Maureille et al. 2001; Volpato et al. 2012; for a recent quantitative assessment and functional interpretation, see Fiorenza et al. 2019). Otherwise, together with a relatively homogeneous distribution between the antimeres of both front and postcanine teeth, the two specimens share a more marked wear on the incisors and canines, which is a typical likely functionally-related Neanderthal feature (Volpato et al. 2012). However, also occlusal molar topography is partially obliterated, including on the M3s. In these two Neanderthal representatives, the thickest enamel is nearly invariably found on the labial (front teeth) and buccal (postcanine dentition) aspects. Their lateral incisors display thicker enamel than the I1s. Interestingly, BD 1's front teeth show slightly thicker enamel compared to Regourdou 1, while no difference is appreciable for the post-canine crowns, showing relatively thicker enamel at the base of the buccal cusps and thinner enamel in the occlusal basin, including in the unworn areas.

\section{Dental tissue proportions}

Tooth tissue proportions in BD 1 are shown in tab. 1. For the tooth size-independent percent of crown that is dentine and pulp (Vcdp/Vc), its values overlap the estimates available for Regourdou 1 (cf. Macchiarelli et al. 2013: tab. 1), some very minor differences uniquely concerning the P3s, the M1s and the M3s, whose proportions are slightly lower in BD 1. In terms of enamel thickness, the P4s and M3s, i.e., the proportionally least worn postcanine crowns in BD 1 (stage 2 to 3 following Smith 1984), have an average 3D RET of 15.3 and 14.6, respectively. Here again, the estimates for this scale-free parameter are comparable to those assessed in Regourdou 1, where BD 1 displays an only slightly higher value for the M3, but not the P4. As previously noted, in BD 1 the roots of the right 11 and $C$ are respectively incomplete and missing, thus limiting tissue proportion estimates to the crown. As shown by the percent of root volume that is cementum, in BD 1 a rather thick layer of cementum covers most roots. Indeed, Vcem/Vrdp ranges from $11.6 \%$, on the left M3, to $43.5 \%$, on the left 11, but no direct comparison can be performed with the pattern displayed by Regourdou 1, as its cementum distribution has not been reported yet.

In BD 1, antimeric differences in tooth tissue proportions (84 cases calculated on 96) are extremely variable, as they range from nearly zero to $92 \%$ (M3 Vcem/Vrdp), the highest values systematically concerning the parameters also or uniquely integrating the radicular components. With this respect, the impact of cementum thickness variation is evident. However, when uniquely the crown is considered, absolute values of asymmetry range from $1 \%$ (M2 Vcdp) to $18.6 \%$ (M1 SEDJ), 37 out of 48 cases showing an asymmetry below $10 \%$. The Vcdp/Vc is in absolute the least asymmetric parameter (range 0.6-4.9\%). Importantly in this study, asymmetry is globally fluctuating, side dominance being nearly equally distributed between the left and the right antimeres ( $51 \%$ vs. $49 \%$, respectively). This is also shown by the three variables Vcdp/Vc, 3D AET and 3D RET (fig. 3).

\section{Radicular dentine thickness distribution}

The standardized cartographies of radicular dentine thickness distribution in four anterior teeth of BD 1 (three left and one right roots) and Regourdou 1 (one left and three right roots) are illustrated in figure 4. The two Neanderthals exhibit a nearly identical repartition pattern, with relatively and absolutely thicker dentine found across the lingual and labial aspects, while the mesial and distal sides systematically display the thinnest dentine, notably towards the root apices. However, in all front teeth suitable for such kind of analysis, BD 1 shows more contrasted maps with relatively thicker radicular dentine spread across a larger surface than measured in Regourdou 1, even if absolutely thickest dentine is found on the right 12 of the latter specimen (c. $3.7 \mathrm{~mm}$ vs. c. 3.2 in $\mathrm{BD}$ 1). Unfortunately, intra-individual asymmetry in both specimens can be only assessed for the 12s. With this respect, the dentine of the right lateral incisor is distinctly 
BD 1

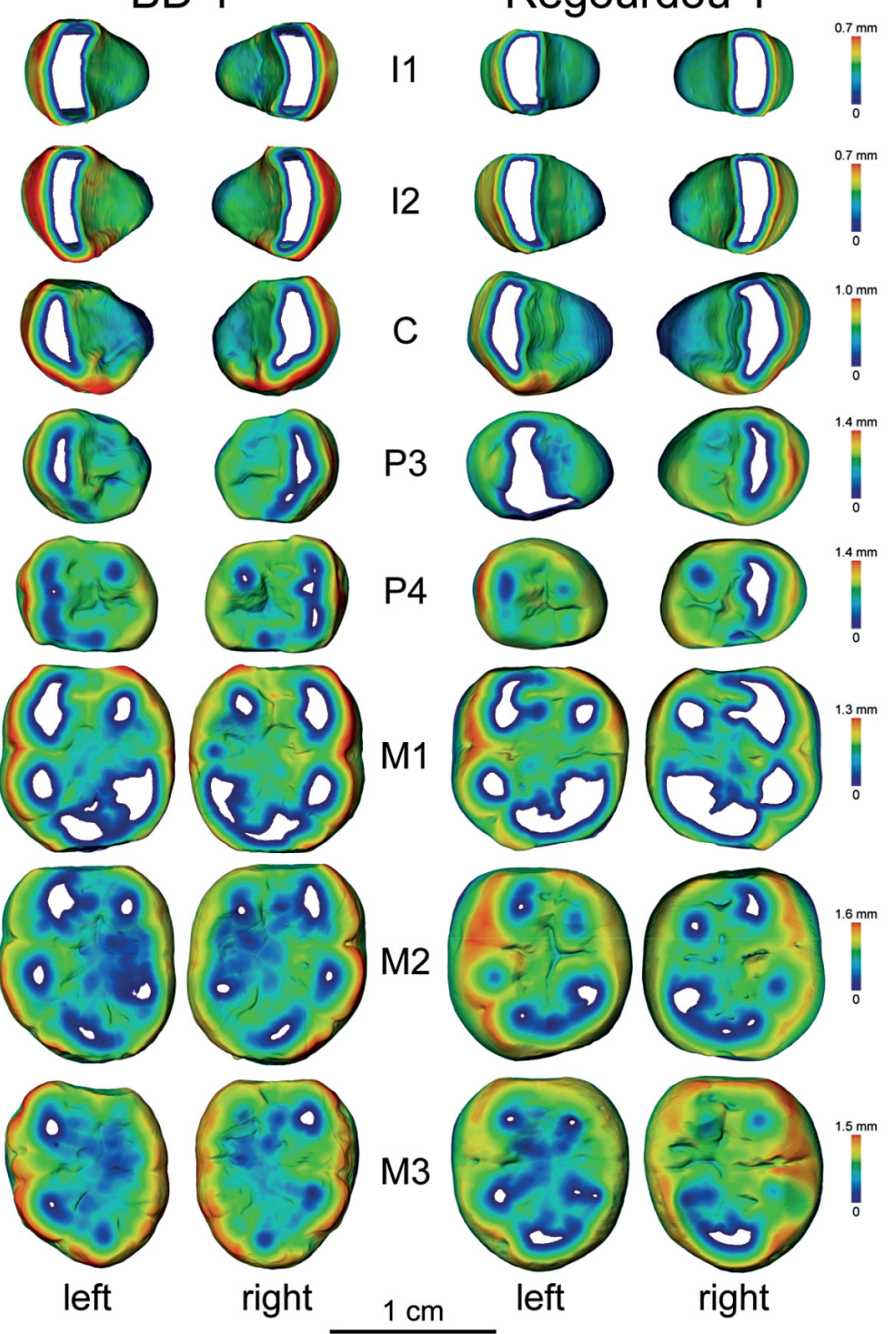

\section{FIGURE 2}

Enamel thickness cartographies of the entire set of virtually reconstructed teeth (11-M3) of the Neanderthal mandibles BD 1 and Regourdou 1. Topographic variation is rendered by a tooth-specific thickness-related chromatic scale ranging from dark blue (thinner enamel) to red (thicker enamel); white areas correspond to complete enamel removal (emerging underlying dentine patches) following occlusal wear. Scale bar: $1 \mathrm{~cm}$.

Cartographies d'épaisseur de l'émail de l'ensemble des dents virtuellement reconstruites (11-M3) des mandibules néandertaliennes $B D 1$ et Regourdou 1. Les variations topographiques sont représentées par une échelle de couleur propre à chaque dent allant du bleu foncé (émail plus fin) au rouge (émail plus épais): les zones blanches correspondent à l'usure de l'émail (îlots de dentine visibles à la surface occlusale). Echelle: $1 \mathrm{~cm}$. thicker and more spread in BD 1 at all investigated sites, while only a modest site-specific left prevalence is found in Regourdou 1.

\section{Cortical bone distribution}

Cortical bone thickness topographic variation (absolute distance values between the periosteal and the endosteal contours) assessed in BD 1 and Regourdou 1 across two homologous bucco-lingual slices virtually extracted at the M1/M2 and M2/M3 positions of both left and right mandibular sides is shown in figure 5 . Even if some sitespecific differences are notable on both slices, especially across the inferior and buccal portions of the corpus, the two specimens show a globally similar distribution pattern, where bone thickness progressively increases from the perialveolar lingual aspect towards the inferior margin, and then progressively thins towards the perialveolar buccal margin. At nearly all sites captured by the two slices, and especially across their inferior portion, BD 1 shows absolutely thinner cortical bone compared to Regourdou 1, except at the buccal aspect of the M1/M2 right slice, where BD 1 exhibits slightly thicker cortical bone than measured in Regourdou 1.

This is also shown by the scale-free Relative Cortical Thickness index (2D RCT). For this parameter, percent asymmetry in BD 1 indicates slight right dominance at both sites (absolute values range: 9.3-12.9\%), while Regourdou 1 shows no asymmetry at M1/M2 level and slight right dominance (-7.5\%) at M2/M3 level (tab. 2)

\section{DISCUSSION AND CONCLUSIONS}

Despite the modest preservation conditions and incompleteness of the supporting mandibular bone, the dentition of the adult Neanderthal specimen BD 1, from the Bourgeois-Delaunay shelter of the La Chaise-deVouthon site complex, Charente (France), is among the best preserved complete lower dentitions from the western European Eemian (OIS 5e) human fossil record (Condemi 2001). The microtomographic-based analysis of its inner structural organization performed in this study allowed a detailed comparison with the homologous features of another exceptionally-preserved Neanderthal permanent dentition: that of the c. $90 \mathrm{~km}$ apart OIS 4 specimen Regourdou 1 (Maureille et al. 2001), likely of similar age at death (Volpato et al. 2012) and of comparable external morphometric characteristics, including the degree of occlusal crown wear (Fiorenza et al. 2019).

By relying upon some previous analyses of the Regourdou 1 mandible and dentition (Maureille et al. 2001; Macchiarelli et al. 2008, 2013; Volpato et al. 2011, 2012; Fiorenza et al. 2019), here we comparatively assessed the 


\begin{tabular}{|c|c|c|c|c|c|c|c|c|c|c|c|c|c|c|}
\hline Tooth & & & $\begin{array}{c}\mathrm{Ve} \\
\left(\mathrm{mm}^{3}\right)\end{array}$ & $\begin{array}{c}\mathrm{Vd} \\
\left(\mathrm{mm}^{3}\right)\end{array}$ & $\begin{array}{c}\mathrm{Vp} \\
\left(\mathrm{mm}^{3}\right)\end{array}$ & $\begin{array}{l}\text { Vcem } \\
\left(\mathrm{mm}^{3}\right)\end{array}$ & $\begin{array}{c}\mathrm{Vt} \\
\left(\mathrm{mm}^{3}\right)\end{array}$ & $\begin{array}{l}\text { Vcdp } \\
\left(\mathrm{mm}^{3}\right)\end{array}$ & $\begin{array}{l}\text { Vrdp } \\
\left(\mathrm{mm}^{3}\right)\end{array}$ & $\begin{array}{l}\text { SEDJ } \\
\left(\mathrm{mm}^{2}\right)\end{array}$ & $\begin{array}{c}\mathrm{Vcdp} / \mathrm{Vc} \\
\text { (\%) }\end{array}$ & $\begin{array}{c}\text { Vcem/Vrdp } \\
\text { (\%) }\end{array}$ & $\begin{array}{c}\text { 3D AET } \\
(\mathrm{mm})\end{array}$ & 3D RET \\
\hline \multirow[t]{3}{*}{ I1 } & & left & 41.98 & 365.23 & 15.89 & 115.29 & 423.10 & 116.21 & 264.91 & 104.13 & 73.46 & 43.52 & 0.40 & 8.26 \\
\hline & & right & 38.83 & - & - & - & - & 101.57 & - & 92.80 & 72.34 & - & 0.42 & 8.97 \\
\hline & $\%$ & asymm. & 7.8 & $\begin{array}{l}- \\
-\end{array}$ & $\begin{array}{l}- \\
-\end{array}$ & $\begin{array}{l}- \\
-\end{array}$ & - & 13.4 & - & 11.5 & 1.5 & - & -3.7 & -8.2 \\
\hline \multirow[t]{3}{*}{ I2 } & & left & 56.80 & 483.34 & 21.93 & 108.59 & 562.07 & 130.63 & 374.38 & 115.40 & 69.69 & 29.01 & 0.49 & 9.70 \\
\hline & & right & 52.92 & 479.63 & 21.91 & 95.95 & 554.47 & 126.05 & 375.43 & 109.05 & 70.43 & 25.56 & 0.49 & 9.68 \\
\hline & $\%$ & asymm. & 71 & 08 & 0.1 & 12.4 & 1.4 & 3.6 & -0.3 & 5.7 & -11 & 12.6 & 1.4 & 0.2 \\
\hline \multirow[t]{3}{*}{ C } & & left & 76.46 & 565.91 & 25.65 & 155.41 & 668.02 & 163.02 & 433.38 & 128.82 & 68.07 & 35.86 & 0.59 & 10.87 \\
\hline & & right & 71.44 & - & - & - & - & 142.93 & - & 116.30 & 66.67 & - & 0.61 & 11.75 \\
\hline & $\%$ & asymm. & 6.8 & - & - & - & - & 13.1 & - & 10.2 & 21 & - & -3.4 & -7.8 \\
\hline \multirow[t]{3}{*}{ P3 } & & left & 77.64 & 382.53 & 17.54 & 75.17 & 477.72 & 113.62 & 286.55 & 106.66 & 59.40 & 26.23 & 0.73 & 15.03 \\
\hline & & right & 77.34 & 351.71 & 19.43 & 91.91 & 448.48 & 114.91 & 256.45 & 109.42 & 59.77 & 35.84 & 0.71 & 14.54 \\
\hline & 8 & asymm. & 0.4 & 8.4 & -10.2 & -20.0 & 6.3 & -1.1 & 111 & -2.6 & -0.6 & -31.0 & 2.9 & 3.3 \\
\hline \multirow[t]{3}{*}{ P4 } & & left & 91.13 & 357.56 & 20.34 & 94.87 & 469.03 & 119.60 & 258.49 & 119.54 & 56.76 & 36.70 & 0.76 & 15.47 \\
\hline & & right & 100.15 & 421.62 & 24.32 & 104.87 & 546.10 & 134.75 & 311.30 & 129.18 & 57.36 & 33.69 & 0.78 & 15.12 \\
\hline & 8 & asymm. & -9.4 & -16.4 & -17.8 & -10.0 & -152 & -11.9 & -18.5 & -78 & -11 & 8.6 & -1.7 & 23 \\
\hline \multirow[t]{3}{*}{ м1 } & & left & 123.14 & 812.81 & 48.27 & 130.09 & 984.22 & 271.38 & 589.96 & 179.84 & 68.79 & 22.05 & 0.68 & 10.58 \\
\hline & & right & 147.34 & 742.25 & 50.58 & 177.93 & 940.17 & 318.27 & 475.00 & 216.80 & 68.36 & 37.46 & 0.68 & 9.95 \\
\hline & $\%$ & asymm. & -17.9 & 91 & -4.7 & -311 & 4.6 & -15.9 & 21.6 & -18.6 & 0.6 & -518 & 0.8 & 61 \\
\hline \multirow[t]{3}{*}{ M2 } & & left & 160.10 & 925.70 & 64.64 & 124.21 & 1150.44 & 313.15 & 612.55 & 220.46 & 66.17 & 20.28 & 0.73 & 10.69 \\
\hline & & right & 184.01 & 981.75 & 65.94 & 130.05 & 1231.69 & 313.44 & 668.43 & 217.32 & 63.01 & 19.46 & 0.85 & 12.46 \\
\hline & $\%$ & asymm. & -13.9 & -59 & -2.0 & -4.6 & -6.8 & -1.0 & -8.7 & 1.4 & 4.9 & 4.1 & -15.3 & -15.3 \\
\hline \multirow[t]{3}{*}{ M3 } & & left & 146.84 & 661.94 & 50.64 & 56.62 & 859.41 & 222.97 & 489.96 & 169.27 & 60.29 & 11.56 & 0.87 & 14.31 \\
\hline & & right & 158.25 & 616.89 & 48.76 & 139.74 & 823.90 & 221.19 & 444.94 & 174.79 & 58.29 & 31.41 & 0.91 & 14.97 \\
\hline & $\%$ & asymm. & -7.5 & 7.0 & 38 & -84.7 & 4.2 & 0.8 & 9.6 & -3.2 & 3.4 & -92.4 & -4.3 & -4.6 \\
\hline
\end{tabular}

\section{- TABLEAU 1 -}

Antimeric variation (\% asymm.; Corruccini et al. 2005) in tooth tissue proportions (variables from Ve to Vcem/Vrdp) and 3D enamel thickness (AET and RET) assessed in the BD 1 Neanderthal mandible. See the text for the meaning of the variables. Negative values indicate right dominance; for each variable, italics and bold indicate the lowest and the highest values, respectively (cf. Macchiarelli et al. 2013: table 1). Note that, because of incomplete/missing root, some variables were not measured/calculated for the right central incisor (I1) and canine (C).

degree of asymmetry in BD 1 of tooth tissue proportions (entire dentition), radicular dentine thickness repartition (anterior teeth), and cortical bone topography of the molar region. Besides their acknowledged taxonomic and phylogenetic significance, such genetically-controlled features are also sensible individual indicators of environmental (including nutritional) and/or systemic physiological perturbations (growth disruption) experienced during development (e.g., Rizk et al. 2013), and also tend to record the variable impact of the biomechanical environment (loading regimes related to masticatory/paramasticatory activities) on the structural organization of dental and bony tissues (rev. in Fiorenza et al. 2019).

Preliminarily, it is anyhow relevant to note that the BD 1's crown and radicular dental endostructural signature is typically Neanderthal (cf. Macchiarelli et al. 2006, 2008, 2013; Olejniczak et al. 2008; Kupczik and Hublin 2010; Bayle et al. 2011, 2017; Prado-Simón et al. 2012; Le Cabec et al. 2013; Martin et al. 2017; Zanolli et al. 2018) and is unambiguously distinct from the fossil and extant modern human patterns (cf. Le Luyer 2016).

In BD 1, asymmetry in tooth tissue proportions is clearly non-directional, as side dominance is nearly equally distributed between the left and the right antimeres. This pattern is even more accentuated than that observed in Regourdou 1, where a right dominance is found in $64 \%$ of cases (Macchiarelli et al. 2013). However, this percentage decreases and approaches the BD 1's condition if the P3s
Variations entre antimères (\% asymm.; Corruccini et al. 2005) des proportions des tissus dentaires (variables de Ve à Vcem/Vrdp) et indices 3D d'épaisseur de l'émail (3D AET et 3D RET) estimées pour la mandibule néandertalienne BD 1. Voir le texte pour la signification des variables. Les valeurs négatives indiquent une dominance du côté droit; pour chaque variable, italique et gras indiquent respectivement les valeurs minimale et maximale (cf. Macchiarelli et al. 2013: table 1). A noter qu'en raison de racines incomplètes/manquantes, certaines variables n'ont pas pu être mesurées/calculées pour l'incisive centrale (I1) et la canine (C).

are excluded from the analysis. In fact, compared to its antimere, Regourdou 1's left third premolar bears unusual semi-circular enamel wear facets likely resulting from some tooth-tool uses for daily task activities (Fiorenza et al. 2019). Also, compared to BD 1, the posterior dentition of Regourdou 1 is characterized by a more asymmetric wear pattern, the right side being more worn than its counterpart (Maureille et al. 2001; Fiorenza et al. 2019), a condition that likely affected the quantitative assessment of at least some among the parameters considered in our analyses.

Similarly to Regourdou 1, fluctuating endostructural asymmetry in BD 1 is globally moderate, notably for the parameters not directly affected by the variably thick coat of radicular cementum present in this specimen and, of course, for those generally poorly affected by moderate occlusal wear. With this respect, it is noteworthy that when BD 1 and Regourdou 1 are compared for the total volume of dentine $(\mathrm{Vd})$ or the surface area of enamel-dentine junction (SEDJ), for example, their degree of asymmetry is comparable (cf. tab. 1 with tab. 1 in Macchiarelli et al. 2013). In some cases, asymmetry does not even exceed the measurement error reported for such kind of variables in tests run for intra- and inter-observer accuracy (e.g., Macchiarelli et al. 2008). Even if currently based on the record from two individuals only, this evidence tends to support previous suggestions that, among Neanderthals, at least nutritional stresses during growth were not especially elevated compared with those affecting several 

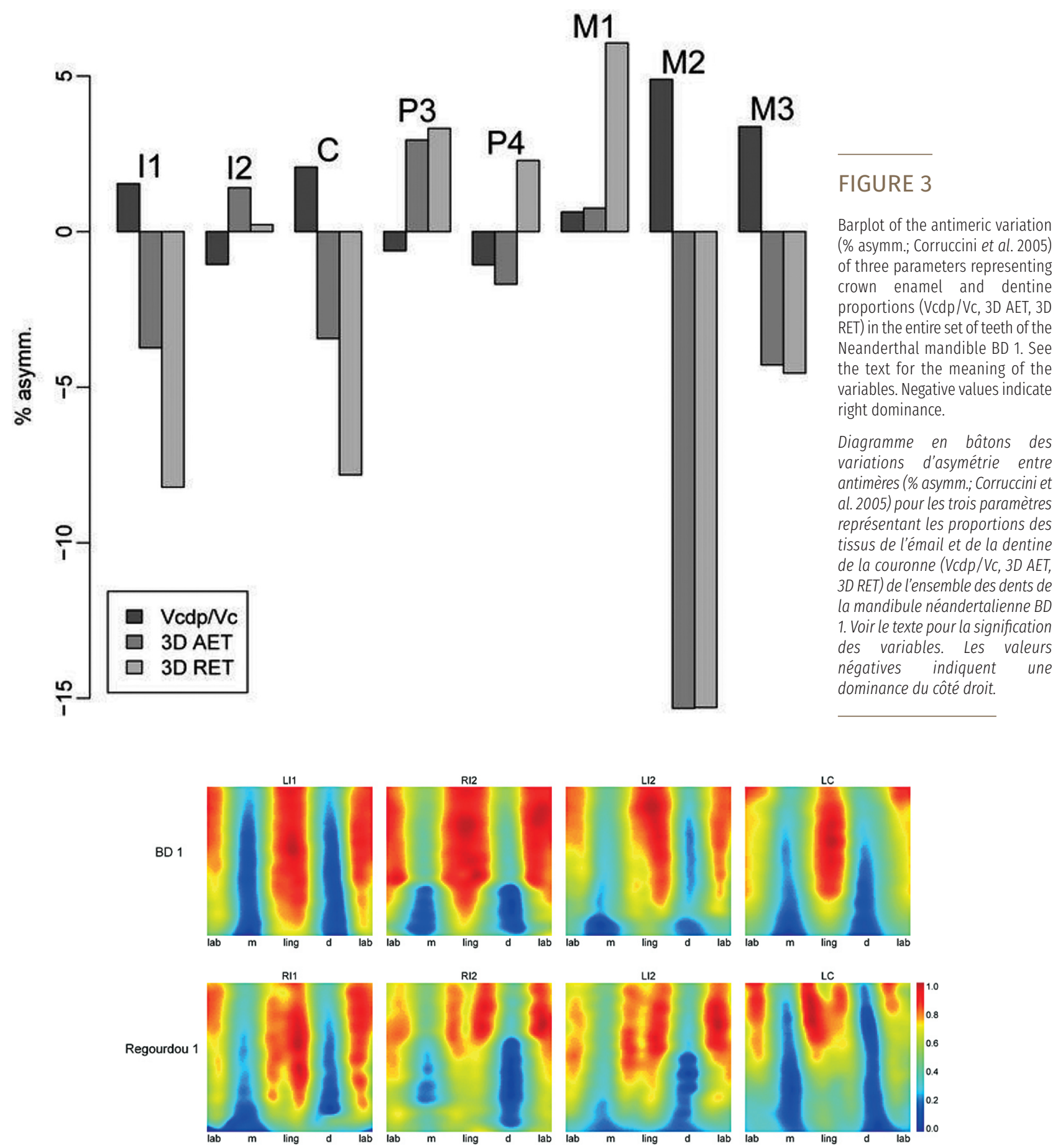

- FIGURE 4 -

Standardized morphometric maps of the virtually unrolled root dentine (15-85\% of the total root length, where $15 \%$ is closer to the dental cervix) of four anterior teeth (incisors and canine) of the Neanderthal mandibles BD 1 and Regourdou 1. Dentine topographic variation is rendered by a thickness-related chromatic scale ranging from dark blue (0) to red (1). LC: left canine; LI1: left central incisor; LI2: left lateral incisor; RI1: right central incisor; RI2: right lateral incisor. d: distal; lab: labial; ling: lingual; m: mesial.

present-day populations (Hutchinson et al. 1997). However, in both BD 1 and Regourdou 1 dental wear has also to be taken into account as additional parameter to any possible developmental noise (Benazzi et al. 2013; Macchiarelli et al. 2013). Finally, it should be pointed out that, at the best
Cartographies morphométriques standardisées de la dentine radiculaire déroulée (15-85\% de la longueur totale de la racine, où $15 \%$ est plus proche du cervix) de quatre dents antérieures (incisives et canines) des mandibules néandertaliennes $B D 1$ et Regourdou 1. Les variations topographiques de la dentine sont représentées par une échelle de couleur propreà chaque dent allant du bleu foncé (0) au rouge (1). LC: canine gauche; L11: incisive centrale gauche; LI2: incisive latérale gauche; RI1: incisive centrale droite; RI2: incisive latérale droite; d: distal; lab: labial; ling: lingual; m: mésial.

of our knowledge, no comparative quantitative data from representative extant/recent human samples is available on tooth tissue proportion antimeric variation, which currently limits our interpretations. 

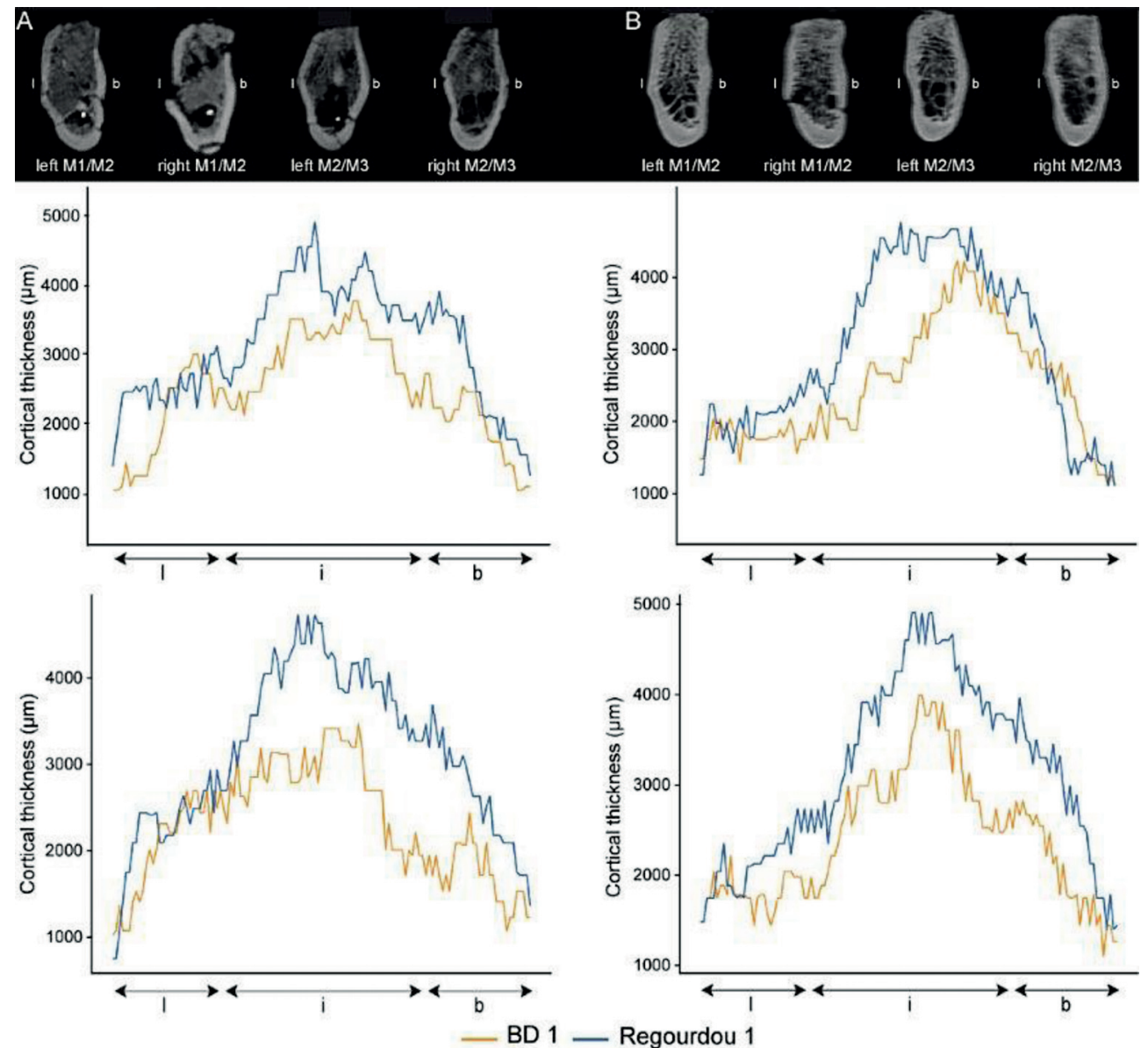

FIGURE 5

Bucco-lingual slices virtually extracted between the first and second molars (M1/M2) and the second and third molars (M2/M3) from the Neanderthal mandibles BD 1 (A) and Regourdou 1 (B) and cortical bone thickness variation (in $\mu \mathrm{m}$ ) measured across these sections: C, left M1/M2 section; D, right $M 1 / M 2$ section; E, left M2/M3 section; F, right M2/M3 section. b: buccal side; i: inferior portion; 1 : lingual side.

Sections bucco-linguales extraites virtuellement entre les premières et secondes molaires (M1/M2) et deuxième et troisièmes molaires (M2/M3) des mandibules néandertaliennes BD 1 (A) et Regourdou 1 (B) et mesures des variations d'épaisseur de l'os cortical (en $\mu m$ m) au niveau de ces sections: C, section M1/M2 gauche; $D$, section M1/M2 droite; E, section M2/M3 gauche; F, section M2/M3 droite. b: aspect buccal; i: portion inférieure; l: aspect lingual.

\section{TABLEAU 2}

\begin{tabular}{c|c|c}
\hline $\begin{array}{c}\text { Virtual slice } \\
\text { position }\end{array}$ & BD 1 & Regourdou 1 \\
\hline M1/M2 left & 10.9 & 15.5 \\
M1/M2 right & 12.4 & 15.5 \\
\% asymm. & -12.9 & 0.0 \\
& & \\
M2/M3 left & 11.3 & 14.2 \\
M2/M3 right & 12.4 & 15.3 \\
\% asymm. & -9.3 & -7.5 \\
\hline
\end{tabular}

Antimeric variation (\% asymm.; Corruccini et al. 2005) of the scale-free bidimensional (2D) Relative Cortical Thickness (2D RCT) index (Cazenave et al. 2017) comparatively assessed in bucco-lingual slices virtually extracted between the first and second molars (M1/M2) and the second and third molars (M2/M3) in the Neanderthal mandibles BD 1 and Regourdou 1. Negative values indicate right dominance.

Variations entre antimères (\% asymm.; Corruccini et al. 2005) de l'indice bidimensionnel (2D) et sans échelle d'épaisseur relative de l'os cortical (2D RCT) (Cazenave et al. 2017) estimées pour les sections bucco-linguales extraites virtuellement entre les premieres et secondes molaires (M1/M2) et deuxième et troisièmes molaires (M2/M3) des mandibules néandertaliennes BD 1 et Regourdou 1. Les valeurs négatives indiquent une dominance du côté droit.

The significance of radicular dentine intra- and interindividual variation is also difficult to interpret because of similar lack of comparative information from controlled reference series, as well as of the paucity of evidence from the human fossil record, limited to a handful of specimens (Bayle et al., 2011; Macchiarelli et al., 2013; Zanolli et al., 2014, 2018). A recent study of the Regourdou 1 mandible has suggested a likely cause-effect functional relationship among uneven masticatory and/or non-masticatory loadings, occlusal crown macrowear, asymmetric variation in radicular dentine and postcanine cortical bone distribution (Fiorenza et al. 2019). However, the relative role of genetic vs. functional factors in the distribution of root dentine is not yet elucidated. Nonetheless, while few studies have investigated the long-term impact on the radicular dentine mechanoreceptors of variably frequent and intense strains and stresses (Dean 2017), the capacity of bone as dynamic tissue to respond to alterations of its mechanical environment is very-well reported, notably for the mandible, where thicker cortical bone is commonly found in areas facing higher strains (e.g., Masumoto et al. 2001; Daegling and Hotzman 2003; Lieberman et al. 2004; Fukase 2007; Fukase and Suwa 2008; Martínez-Gomis et al. 2009; Holmes and Ruff 2011; Gröning et al. 2012; but see Ichim et al. 2007). Unfortunately, the evidence from the hominin/human fossil record is extremely limited (e.g., Daegling and Grine 1991; Grine and Daegling, 2017; Zanolli et al. 2017; Fiorenza et al. 2019), the reason of the interest here of a direct comparison between BD 1 and Regourdou 1 for evaluating if markedly uneven biomechanical demands and preferences over the molar region may have resulted into distinct cortical bone asymmetry. Limitedly 
to the evidence captured from two virtual sections extracted across the $\mathrm{M} 1 / \mathrm{M} 2$ and $\mathrm{M} 2 / \mathrm{M} 3$ boundaries, this does not seem to be the case in the two Neanderthal individuals, even if a slight right dominance is found in BD 1.

In conclusion, the results scattered from the present endostructural analysis of the OIS 5e BD 1 specimen from Bourgeois-Delaunay, which integrate and expand similar research performed on the mandible and dentition of the OIS 4 individual Regourdou 1 (Macchiarelli et al. 2008, 2013; Volpato et al. 2011, 2012; Fiorenza et al. 2019), provide new original evidence on antimeric variation in Neanderthal osteodental organization. Nonetheless, extensive methodological research to be developed on the patterns of age- and sex-related endostructural variation displayed by human population samples from diverse chrono-geographic, socio-economic and biocultural contexts is needed to more confidently evaluate the evolutionary and adaptive significance of the signals from the fossil record

\section{ACKNOWLEDGMENTS}

The fossil specimen BD 1 is curated at the Musée d'Angoulême, while Regourdou 1 is at the Musée d'Art et d'Archéologie du Périgord, Périgueux. For access to Regourdou 1, we are indebted to F. Couturas, G. Marchesseau and V. Merlin-Anglade. Scanning of both mandibles BD 1 and Regourdou 1 was performed within the framework of the European «TNT Project» at the ESRF beamline ID 17 (Grenoble) thanks to the local collaboration provided by A. Bravin, C. Nemoz and P. Tafforeau. For contribution to the documentation and analysis of both fossils, we thank P. Bayle, S. Benazzi, A. Bergeret, L. Bondioli, L. Fiorenza, F. Gröning, O. Kullmer, and especially V. Volpato. For discussion, we also thank C. Dean, L.C. Fitton, B. Maureille, P. O'Higgins, P. Sémal and B. Vandermeersch. Among the authors, J.-F.T., A.M. and R.M. acknowledge the stimulating role and unique contribution provided by $A$. Debénath during the European «TNT Project».

\section{BIBLIOGRAPHIC REFERENCES}

ARMAND D. 1998 - La faune de la grotte BourgeoisDelaunay, commune de La Chaise-de-Vouthon (Charente) Résultats préliminaires. Paleo, 10: 77-86.

BADDELEY A., RUBAK E. and TURNER R. 2015 - Spatial point patterns: methodology and applications with R. Chapman and Hall/CRC Press, London, 828 p.

BAYLE P., BONDIOLI L., MACCHIARELLI R., MAZURIER A., PUYMERAIL L., VOLPATO V. and ZANOLLI C. 2011 - Three-dimensional imaging and quantitative characterization of human fossil remains. Examples from the NESPOS database. In: Pleistocene databases. Acquisition, storing, sharing, Macchiarelli R., Weniger G.-C. (eds), Wissenschaftliche Schriften des Neanderthal Museums 4, Mettmann, p. 29-46.

BAYLE P., LE LUYER M. and ROBSON BROWN K.A. 2017 - The dental remains: enamel thickness, and tissue proportions. In: The people of Palomas: Neandertals from the Sima de las Palomas, Cabeza Gordo, southeastern Spain, Trinkaus E., Walker M.J. (eds), Texas A\&M University Press, College Station, pp. 115-137.
BENAZZI S., NGUYEN H.N. KULLMER O. and HUBLIN J.-J. 2013 Unravelling the functional biomechanics of dental features and tooth wear. PLoS One, 8: e69990.

BERTRAN P. 1999 - Dynamique des dépôts de la grotte Bourgeois-Delaunay (La Chaise-de-Vouthon, Charente): apport de la micromorphologie. Paleo, 11: 9-18.

BLACKWELL B.A., PORAT N., SCHWARCZ H.P. and DEBÉNATH A. 1992 - ESR dating of tooth enamel: comparison with ${ }^{230} \mathrm{Th} /{ }^{234} \mathrm{U}$ speleothem dates at La Chaise-deVouthon (Charente), France. Quaternary Science Reviews, 11: $231-244$

BLACKWELL B.A., RUTTER N.W., and DEBÉNATH A. 1990 Amino acid racemization analysis of mammalian bones and teeth from La Chaise-de-Vouthon (Charente), France. Geoarchaeology, 5: 121-147.

BLACKWELL B.A., SCHWARCZ H.P. and DEBÉNATH A. 1983 Absolute dating of hominids and Paleolithic artifacts of the cave of La Chaise-de-Vouthon (Charente), France. Journal of Archaeological Science, 10: 493-513.

BONDIOLI L., BAYLE P., DEAN C., MAZURIER A., PUYMERAIL L., RUFF C., STOCK J.T., VOLPATO V., ZANOLLI C. and MACCHIARELLI R. 2010 - Morphometric maps of long bone shafts and dental roots for imaging topographic thickness variation. American Journal of Physical Anthropology, 142: 328-334

BONHOMME V., PICQ S., GAUCHEREL C. and CLAUDE J. 2014 Momocs: outline analysis using R. Journal of Statistical Software, 56: 1-24.

BOUCHUD P. and BOUCHUD J. 1953 - La petite faune de la grotte de La Chaise (Charente). Bulletin de la Société préhistorique de France, 50: 170-177.

BRAGA J., THACKERAY J.F., SUBSOL G., KAHN J.L., MARET D., TREIL J. and BECK A. 2010 - The enamel-dentine junction in the postcanine dentition of Australopithecus africanus: intra individual metameric and antimeric variation. Journal of Anatomy, 216: 62-79.

CAZENAVE M., BRAGA J., OETTLÉ A. THACKERAY J.F., DE BEER F., HOFFMAN J., ENDALAMAW M., ENGDA REDAE B., PUYMERAIL L. and MACCHIARELLI R. 2017 - Inner structural organization of the distal humerus in Paranthropus and Homo. Comptes Rendus Palevol, 16: 521-532.

CONDEMI S. 2001 - Les Néandertaliens de La Chaise. C.T.H.S., Paris, $178 \mathrm{p}$.

COQUEUGNIOT H., LIGUORO D., TILLIER A.-M. and CHECH M. 1996 - L'os frontal immature de la Chaise S.15 (Abri Suard, La Chaise-de-Vouthon, Charente). Phylogénie et pathologie. Paleo, 8: 9-18.

CORRUCCINI R.S., TOWNSEND G.C and SCHWERDT W. 2005 Correspondence between enamel hypoplasia and odontometric bilateral asymmetry in Australian twins. American Journal of Physical Anthropology, 126: 177-182. 
COUCHOUD I. 2006 - Étude pétrographique et isotopique de spéléothèmes du Sud-Ouest de la France formés en contexte archéologique: contribution à la connaissance des paléoclimats régionaux du Stade Isotopique 5. Thèse de Doctorat. Université Bordeaux-1, 347 p.

DAEGLING D.J. and GRINE F.E. 1991 - Compact bone distribution and biomechanics of early hominid mandibles. American Journal of Physical Anthropology, 86: 321-339.

DAEGLING D.J. and HOTZMAN J.L. 2003 - Functional significance of cortical bone distribution in anthropoid mandibles: an in vitro assessment of bone strain under combined loads. American Journal of Physical Anthropology, 122, 38-50.

DAVID P. and BORDES F. 1950 - Découverte d'une calotte crânienne fragmentaire et de dents humaines dans un niveau moustérien de La Chaise (Charente). C.R. de l'Académie des Sciences de Paris, 230: 779-780.

DAVID P. and PIVETEAU J. 1953a - Station de La Chaise. IV. Paléontologie humaine. Bulletins et Mémoires de la Société Archéologique et Historique de la Charente: 19-26.

DAVID P. and PIVETEAU J. 1953b - Station de La Chaise (Commune de Vouthon), grottes Suard, fouillés par David. Paléontologie humaine. Bulletin et Mémoires de la Société Historique et Archéologique de la Charente: 13-20.

DAVID P. and PRAT F. 1965 - Considérations sur les faunes de la Chaise (commune de Vouthon, Charente). Abris Suard et Bourgeois Delaunay. Bulletin de l'Association Française pour l'Étude du Quaternaire, 3-4: 222-231.

DEAN C. 2017 - How the microstructure of dentine can contribute to reconstructing developing dentitions and the lives of hominoids and hominins. In: Hominin biomechanics, virtual anatomy and inner structural morphology: from head to toe. A tribute to Laurent Puymerail, Macchiarelli R., Zanolli C. (eds), Comptes Rendus Palevol, 16: 557-571.

DEBÉNATH A. 1967 - Découverte d'une mandibule humaine à la Chaise-de-Vouthon (Charente). C.R. de l'Académie des Sciences de Paris, 265: 1170-1171.

DEBÉNATH A. 1974a - Recherches sur les terrains quaternaires charentais et les industries qui leur sont associées. Thèse de Doctorat. Université de Bordeaux 1, 678 p.

DEBÉNATH A. 1974b - Position stratigraphique des restes humains antéwürmiens de Charente. Bulletins et Mémoires de la Société d'Anthropologie de Paris, 13: 417-426.

DEBÉNATH A. 1977 - The latest finds of antewürmian human remains in Charente (France). Journal of Human Evolution, 6: 297-302.

DEBÉNATH A. 1992 - Bibliographie des sites de La Chaisede-Vouthon (Charente). Bulletin et Mémoires de la Société Historique et Archéologique de la Charente: 84-100.DEBÉNATH A. 2006 - Néanderthaliens et Cro-Magnons. Les temps glaciaires dans le Bassin de la Charente. Le Croît Vif, Paris, 356 p.
DEBÉNATH A. and PIVETEAU J. 1969 - Nouvelles découvertes de restes humains fossiles à La Chaise de Vouthon (Charente). Position stratigraphique des restes humains de La Chaise (abri Bourgeois-Delaunay). C.R. de l'Académie des Sciences de Paris, 269: 24-28.

DEBÉNATH A. and TOURNEPICHE J.-F. 1996 - Préhistoire de la Charente. G.E.R.M.A., Angoulême, 80 p.

FIORENZA L., BENAZZI S., KULLMER O., ZAMPIROLO G., MAZURIER A., ZANOLLI C. and MACCHIARELLI R. 2019 - Dental macrowear and cortical bone distribution of the Neanderthal mandible from Regourdou (Dordogne, Southwestern France). Journal of Human Evolution, 132: 174-188.

FUKASE H. 2007 - Functional significance of bone distribution in the human mandibular symphysis. Anthropological Science, 115: 55-62.

FUKASE H. and SUWA G. 2008 - Growth-related changes in prehistoric Jomon and modern Japanese mandibles with emphasis on cortical bone distribution. American Journal of Physical Anthropology, 136: 441-454.

GENET-VARCIN E. 1974 - Etude des dents humaines isolées provenant des grottes de la Chaise-de-Vouthon (Charente). Bulletins et Mémoires de la Société d'Anthropologie de Paris, 1: 373-384.

GENET-VARCIN E. 1975a - Etude des dents humaines isolées provenant des grottes de la Chaise-de-Vouthon (Charente). Bulletins et Mémoires de la Société d'Anthropologie de Paris, 2: 129-141.

GENET-VARCIN E. 1975b - Etude des dents humaines isolées provenant des grottes de la Chaise-de-Vouthon (Charente). Bulletins et Mémoires de la Société d'Anthropologie de Paris, 2: 277-286.

GENET-VARCIN E. 1976 - Etude des dents humaines isolées provenant des grottes de la Chaise-de-Vouthon (Charente). Bulletins et Mémoires de la Société d'Anthropologie de Paris, 3: 243-259.

GRIGGO C. 1996 - Etablissement de courbes climatiques quantifiées à partir des communautés animales pléistocènes suivi d'une application aux gisements de l'abri Suard et de la grotte du Bois Ragot (Vienne). Paleo, 8: 81-97.

GRINE F.E. and DAEGLING D.J. 2017 - Functional morphology, biomechanics and the retrodiction of early hominin diets. In: Hominin biomechanics, virtual anatomy and inner structural morphology: from head to toe. A tribute to Laurent Puymerail, Macchiarelli R., Zanolli C. (eds), Comptes Rendus Palevol 16: 613-631.

GRÖNING F., FAGAN M.J. and O'HIGGINS P. 2012 - Modeling the human mandible under masticatory loads: which input variables are important? Anatomical Record, 295: 853-863.

GUATELLI-STEINBERG D., SCIULLI P.W. and EDGAR H.H.J. 2006 - Dental fluctuating asymmetry in the Gullah: tests of hypotheses regarding developmental stability in deciduous vs. permanent and male vs. female teeth. American Journal of Physical Anthropology, 129: 427-434. 
HOLMES M.A. and RUFF C.B. 2011 - Dietary effects on development of the human mandibular corpus. American Journal of Physical Anthropology, 145: 615-628.

HOOVER K.C., CORRUCCINI R.S., BONDIOLI L. and MACCHIARELLI R. 2005 - Exploring the relationship between hypoplasia and odontometric asymmetry in Isola Sacra, an Imperial Roman necropolis. American Journal of Human Biology, 17: 752-764.

HUBLIN J.-J. 1980 - La Chaise Suard, Engis 2 et La Quina H18: développement de la morphologie occipitale externe chez l'enfant prénéandertalien et néandertalien. C.R. de l'Académie des Sciences de Paris, 270: 42-45.

HUTCHINSON D.L., LARSEN C.S. and CHOI I. 1997 - Stressed to the max? Physiological perturbation in the Krapina Neandertals. Current Anthropology, 38: 904-914.

ICHIM I., KIESER J.A. and SWAIN M.V. 2007 - Functional significance of strain distribution in the human mandible under masticatory load: numerical predictions. Archives of Oral Biology, 52: 465-473.

KONO R. 2004 - Molar enamel thickness and distribution patterns in extant great apes and humans: new insights based on a 3-dimensional whole crown perspective. Anthropological Science, 112: 121-146.

KRUKOFF S. 1979 - L'occipital de La Chaise (Suard), caractères métriques, distances de forme et de format. C.R. de l'Académie des Sciences de Paris, 270: 42-45.

KUPCZIK K. and HUBLIN J.-J. - 2010. Mandibular molar root morphology in Neanderthals and Late Pleistocene and recent Homo sapiens. Journal of Human Evolution, 59: 525-541.

LACOMBE J.P. 1977 - Etude anatomique d'un pariétal antewürmien provenant du gisement de La Chaise de Vouthon (Charente). Sa place parmi les fossiles humains antenéandertaliens. Thèse de Doctorat. Université de Bordeaux II, $99 \mathrm{p.}$

LE CABEC A., GUNZ P., KUPCZIK K., BRAGA J. and HUBLIN J.-J. 2013 - Anterior tooth root morphology and size in Neanderthals: taxonomic and functional implications. Journal of Human Evolution, 64: 169-193.

LEGOUX P. 1976 - Les dents de la Chaise-de-Vouthon. Etude pathologique et radiologique. Bulletins et Mémoires de la Société d'Anthropologie de Paris, 3: 345-361.

LE LUYER M. 2016 - Évolution dentaire dans les populations humaines de la fin du Pléistocène et du début de l'Holocène (19000-5500 cal. BP): une approche intégrée des structures externe et interne des couronnes pour le Bassin Aquitain et ses marges. Thèse de Doctorat. Université de Bordeaux, $484 \mathrm{p}$.

LIEBERMAN D.E., KROVITZ G.E., YATES F.W., DEVLIN M. and ST. CLAIRE M. 2004 - Effects of food processing on masticatory strain and craniofacial growth in a retrognathic face. Journal of Human Evolution, 46: 655-677.
MACCHIARELLI R., BAYLE P., BONDIOLI L., MAZURIER A. and ZANOLLI C. 2013 - From outer to inner structural morphology in dental anthropology. The integration of the third dimension in the visualization and quantitative analysis of fossil remains. In: Anthropological perspectives on tooth morphology. Genetics, evolution, variation, Scott G.R., Irish J.D. (eds), Cambridge University Press, Cambridge, p. 250-277.

MACCHIARELLI R., BONDIOLI L., DEBÉNATH A., MAZURIER A., TOURNEPICHE J.-F., BIRCH W. and DEAN C. 2006 - HOW Neanderthal molar teeth grew. Nature, 444: 748-751.

MACCHIARELLI R., BONDIOLI L. and MAZURIER A. 2008 Virtual dentitions: touching the hidden evidence. In: Technique and application in dental anthropology, Irish J.D., Nelson G.C. (eds), Cambridge University Press, Cambridge, p. 426-448.

MACCHIARELLI R., MAZURIER A. and VOLPATO V. 2007 L'apport des nouvelles technologies à l'étude des Néandertaliens. In: Les Néandertaliens. Biologie et culture, Vandermeersch B., Maureille B. (eds), Editions du Comité des travaux historiques et scientifiques, Paris, p. 169-179.

MARTIN M.R.G., HUBLIN J.-J., GUNZ P. and SKINNER M.M. 2017 The morphology of the enamel-dentine junction in Neanderthal molars: gross morphology, non-metric traits, and temporal trends. Journal of Human Evolution, 103: 20-44.

MARTÍNEZ-GOMIS J., LUJAN-CLIMENT M., PALAU S., BIZAR J., SALSENCH J. and PERAIRE M. 2009 - Relationship between chewing side preference and handedness and lateral asymmetry of peripheral factors. Archives of Oral Biology, 54: 101-107.

MASUMOTO T., HAYASHI I., KAWAMURA A., TANAKA K. and KASAI K. 2001 - Relationships among facial type, buccolingual molar inclination, and cortical bone thickness of the mandible. European Journal of Orthodontics, 23: 15-23.

MAUREILLE B., GÓMEZ-OLIVENCIA A., COUTUREVESCHAMBRE C., MADELAINE S. and HOLLIDAY T. 2015b Nouveaux restes humains provenant du gisement de Regourdou (Montignac-sur-Vézère, Dordogne, France). Paleo, 26: 117-138.

MAUREILLE B., HOLLIDAY T., ROYER A., PELLETIER M., MADELAINE S., LACRAMPE-CUYAUBÈRE F., MUTH X., LE GUEUT E., COUTURE-VESCHAMBRE C., GÓMEZ-OLIVENCIA A., DISCAMPS E., TEXIER J.P., TURQ A. and LAHAYE C. 2015a Importance des données de terrain pour la compréhension d'un potentiel dépôt funéraire moustérien: le cas du squelette de Regourdou 1 (Montignac-sur-Vézère, Dordogne, France). Paleo, 26: 139-159.

MAUREILLE B., ROUGIER H., HOUET F. and VANDERMEERSCH B. 2001 - Les dents inférieures du Néandertalien Regourdou 1 (site Regourdou, commune de Montignac, Dordogne): analyses métriques et comparatives. Paleo, 13: 183-200. 
OLEJNICZAK A.J., SMITH T.M., FEENEY R.N.M., MACCHIARELLI R., MAZURIER A., BONDIOLI L., ROSAS A., FORTEA J., DE LA RASILLA M., GARCIA-TABERNERO A., RADOVČIĆ J., SKINNER M.M., TOUSSAINT M. and HUBLIN J.-J. 2008 - Dental tissue proportions and enamel thickness in Neandertal and modern human molars. Journal of Human Evolution, 55: $12-23$.

PEBESMA E.J. 2004 - Multivariable geostatistics in S: the gstat package. Computational Geosciences, 30, 683-691.

PIVETEAU J. 1955 - Remarques sur la structure de l'Homme moustérien (gisement de La Chaise, Charente). Quaternaria, 2: 69-73.

PIVETEAU J. 1959 - Les restes humains de la grotte de Regourdou (Dordogne). Comptes Rendus de l'Académie des Sciences de Paris, 248, 40-44.

PIVETEAU J. 1970 - Les grottes de La Chaise (Charente). L'Homme de l'abri Suard. Annales de Paléontologie des Vertébrés, 56: 175-225.

PIVETEAU J. and CONDEMI S. 1988 - L'os temporal RissWürm (BD 7) provenant de la grotte de La Chaise (abri Bourgeois-Delaunay). In: L'Homme de Néandertal, vol. 3. L'anatomie, Trinkaus E. ed., E.R.A.U.L. 30, Liège, p. 105-110.

PRADO-SIMÓN L., MARTINÓN-TORRES M., BACA P., OLEJNICZAK A.J., GÓMEZ-ROBLES A., LAPRESA M., ARSUAGA J.L. and BERMÚDEZ DE CASTRO J.-M. 2012 - Threedimensional evaluation of root canal morphology in lower second premolars of Early and Middle Pleistocene human populations from Atapuerca (Burgos, Spain). American Journal of Physical Anthropology, 147: 452-461.

PUYMERAIL L., CONDEMI S. and DEBÉNATH A. 2013 Comparative structural analysis of the Neanderthal femoral shafts BD 5 (MIS 5e) and CDV-Tour 1 (MIS 3) from La Chaise-de- Vouthon, Charente, France. Paleo, 24: 257-270.

PUYMERAIL L., VOLPATO V., DEBÉNATH A., MAZURIER A., TOURNEPICHE J.-F. and MACCHIARELLI R. 2012 - A Neanderthal partial femoral diaphysis from the «grotte de la Tour», La Chaise-de-Vouthon (Charente, France): outer morphology and endostructural organization. Comptes Rendus Palevol, 11: 581-593.

R DEVELOPMENT CORE TEAM. 2019 - R: A language and environment for statistical computing. R Foundation for Statistical Computing, Vienna. http://www.R-project.org.

RIZK O.T., GRIECO T.M., HOLMES M.W. and HLUSKO L.J. 2013 Using geometric morphometrics to study the mechanisms that pattern primate dental variation. In: Anthropological perspectives on tooth morphology. Genetics, evolution, variation, Scott G.R., Irish J.D. (eds), Cambridge University Press, Cambridge, p. 126-169.

SABAN R. 1978 - Les pariétaux humains de La Chaise (grotte Suard) et leur empreintes vasculaires (veines méningées moyennes). C.R. de l'Académie des Sciences de Paris, 287: $111-1114$.

SCHLAGER S. 2017 - Morpho and Rvcg - shape analysis in R. In: Statistical shape and deformation analysis, Zheng G., Li S., Szekely G. (eds), Academic Press, London, p. 217-256.
SCHNEIDER C.A., RASBAND W.S. and ELICEIRI K.W. 2012 - NIH Image to Image): 25 years of image analysis. Nature Methods, 9: 671-675.

SCHVOERER M., ROUANET J.F., NAVAILLES H. and DEBÉNATH A. 1977 - Datation absolue par thermoluminescence des restes humains antéwürmiens de l'abri Suard à la Chaise de Vouthon (Charente). C.R. de l'Académie des Sciences de Paris, 287: 1979-1982.

SCHWARCZ H.P. and DÉBÉNATH A. 1979 - Datation absolue des restes humains de La Chaise-de-Vouthon (Charente) au moyen du déséquilibre des séries d'Uranium. C.R. Académie des Science Paris, Ser II, 288: 1155-1157.

SCOTT G.R., TURNER II C.G., TOWNSEND G.C. and MARTINÓNTORRES M. 2018 - The anthropology of modern human teeth. Dental morphology and its variation in recent and fossil Homo sapiens. Cambridge University Press, Cambridge, 396 p.

SMITH H.B. 1984 - Patterns of molar wear in hunter-gatherers and agriculturalists. American Journal of Physical Anthropology, 63: 39-56.

TEILHOL V. 2001 - Contribution à l'étude individuelle des ossements d'enfants de La Chaise-de-Vouthon (Charente, France): approche paléodémographique, paléoethnologique, aspect morphologique et étude métrique. Place phylogénique des enfants de La Chaise. Thèse de Doctorat. Université de Perpignan, Perpignan, 269 p.

TEILHOL V. 2003 - Les os de la voûte crânienne des enfants de l'abri Suard (La Chaise, Charente, France). C.R. Palevol, 2: 289-290.

THOMA A 1975 - L'occipital de la grotte Bourgeois-Delaunay (La Chaise, Charente). Etude biométrique. C.R. de l'Académie des Sciences de Paris, 281: 1821-1824.

TILLIER A.-M. and GENET-VARCIN E. 1980 - La plus ancienne mandibule d'enfant découverte en France dans le gisement de La Chaise de Vouthon (Abri Suard) en Charente. Zeitschrift für Morphologie und Anthropologie, 71: 196-214.

TOURNEPICHE J.-F. 1996 - Les grands mammifères pléistocènes de Poitou-Charente. Paleo, 8: 109-141.

TOURNEPICHE J.-F. 1998 - Géologie de la Charente. G.E.R.M.A., Angoulême, 141 p.

TOURNEPICHE J.-F. 2010 - Les faunes pléistocènes du bassin de la Charente. Musée d'Angoulême, Angoulême, 30 p.

VIEILLEVIGNE E., BOURGUIGNON L., ORTEGA I. and GUIBERT P. 2008 - Analyse croisée des données chronologiques et des industries lithiques dans le grand sud-ouest de la France (OIS 10 à 3). Paleo, 20: 145-166.

VOLPATO V., GRÖNING F., FIORENZA L., BENAZZI S., KULLMER O. and MACCHIARELLI R. 2011 - Distribution osseuse et morphologie structurale de la mandibule néandertalienne Regourdou 1. Bulletins et Mémoires de la Société d'Anthropologie de Paris, 23: S39-S40. 
VOLPATO V., MACCHIARELLI R., GUATELLI-STEINBERG D., FIORE I., BONDIOLI L. and FRAYER D.W. 2012 - Hand to mouth in a Neandertal: right handedness in Regourdou 1. PLoS One, 7: e43949.

WICKMAN H. 2016 - ggplot2: elegant graphics for data analysis. Springer-Verlag, New York. ggplot2.tidyverse.org.

ZANOLLI C. 2015 - Molar crown inner structural organization in Javanese Homo erectus. American Journal of Physical Anthropology 156: 148-157.

ZANOLLI C., BONDIOLI L., COPPA A., DEAN M.C., BAYLE P., CANDILIO F., CAPUANI S., DREOSSI D., FIORE I., FRAYER D.W., LIBSEKAL Y., MANCINI L., ROOK L., MEDIN TEKLE T., TUNIZ C. and MACCHIARELLI R. 2014 - The late Early Pleistocene human dental remains from Uadi Aalad and Mulhuli-Amo (Buia), Eritrean Danakil: macromorphology and microstructure. Journal of Human Evolution, 74: 96-113.
ZANOLLI C., DEAN M.C., ASSEFA Y., BAYLE P., BRAGA J., CONDEMI S., ENDALAMAW M., REDAE B.E. and MACCHIARELLI R. 2017 - Structural organization and tooth development in a Homo aff. erectus juvenile mandible from the Early Pleistocene site of Garba IV at Melka Kunture, Ethiopian highlands. American Journal of Physical Anthropology, 162: 533-549.

ZANOLLI C., MARTINÓN-TORRES M., BERNARDINI F., BOSCHIAN G., COPPA A., DREOSSI D., MANCINI L., MARTINEZZ DE PINILLOS M., MARTÍN-FRANCÉS L., BERMÚDEZ DE CASTRO J.M., TOZZI C., TUNIZ C. and MACCHIARELLI R. 2018 The Middle Pleistocene (MIS 12) human dental remains from Fontana Ranuccio (Latium) and Visogliano (FriuliVenezia Giulia), Italy. A comparative high resolution endostructural assessment. PLoS One, 13: e0189773. 